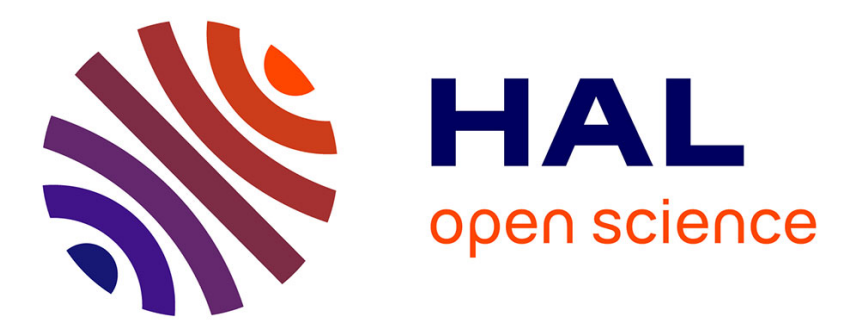

\title{
Magnetic Phase Transformation in the RE(Mn0.5B0.5)O3 Perovskites (RE is a Rare Earth Ion, $\mathrm{B}-\mathrm{Ni}, \mathrm{Co})$
}

\author{
I. Troyanchuk, H. Szymczak, N. Samsonenko, A. Nabialek
}

\section{- To cite this version:}

I. Troyanchuk, H. Szymczak, N. Samsonenko, A. Nabialek. Magnetic Phase Transformation in the $\mathrm{RE}(\mathrm{Mn} 0.5 \mathrm{~B} 0.5) \mathrm{O} 3$ Perovskites (RE is a Rare Earth Ion, B-Ni, Co). Journal de Physique IV Proceedings, 1997, 07 (C1), pp.C1-357-C1-358. 10.1051/jp4:19971145 . jpa-00254789

\section{HAL Id: jpa-00254789 https://hal.science/jpa-00254789}

Submitted on 1 Jan 1997

HAL is a multi-disciplinary open access archive for the deposit and dissemination of scientific research documents, whether they are published or not. The documents may come from teaching and research institutions in France or abroad, or from public or private research centers.
L'archive ouverte pluridisciplinaire HAL, est destinée au dépôt et à la diffusion de documents scientifiques de niveau recherche, publiés ou non, émanant des établissements d'enseignement et de recherche français ou étrangers, des laboratoires publics ou privés. 


\title{
Magnetic Phase Transformation in the $\mathrm{RE}\left(\mathrm{Mn}_{0.5} \mathrm{~B}_{0.5}\right) \mathrm{O}_{3}$ Perovskites $(\mathrm{RE}$ is a Rare Earth Ion, B-Ni, Co)
}

\author{
I.O. Troyanchuk, H. Szymczak*, N.V. Samsonenko and A. Nabialek* \\ Institute of Physics of Solids and Semiconductors, Academy of Sciences of Belarus, P. Brovki 17, \\ Minsk 220072, Belarus \\ * Institute of Physics, Polish Academy of Sciences, Al. Lotnikow 32/46, 02-668 Warsaw, Poland
}

\begin{abstract}
A magnetic study of perovskites $\mathrm{RE}\left(\mathrm{Mn}_{1-\mathrm{x}} \mathrm{B}_{\mathrm{x}}\right) \mathrm{O}_{3}(\mathrm{RE}=\mathrm{Eu}, \mathrm{Gd}, \mathrm{Tb}, \mathrm{Dy}, \mathrm{Y} ; \mathrm{B}=\mathrm{Ni}, \mathrm{Co})$ is reported. It is found that investigated perovskites are nonhomogenous ferromagnets with relatively high Curie temperatures. The magnetic anisotropy of $\mathrm{Ni}$-containing perovskites is much lower than that of Co-containing ones. It is supposed that domains with different charge state of ions and magnetic structure coexist in a wide range of $\mathrm{Co}$ - and $\mathrm{Mn}$ - concentrations. The metamagnetic behavior has been observed for $\mathrm{RE}\left(\mathrm{Mn}_{0.5 \mathrm{~S}} \mathrm{Co}_{0.5}\right) \mathrm{O}_{3}$ perovskites $(\mathrm{RE}=\mathrm{Gd}, \mathrm{Tb}, \mathrm{Dy}, \mathrm{Y})$.
\end{abstract}

\section{INTRODUCTION}

The structure and properties of the compounds on the base of $\mathrm{LaMnO}_{3}$ were a subject of many investigations. In $\mathrm{La}_{1-\mathrm{x}} \mathrm{Sr}_{\mathrm{x}} \mathrm{MnO}_{3}$ the insulator-metal and antiferromagnetic-ferromagnetic transitions are brought about by doping charge carriers in a parent insulating $\mathrm{LaMnO}_{3}$. These compounds show a colossal magnetoresistance near their $\mathrm{Curie}$ temperatures. However, there is another class of compounds exhibiting substitutionally driven antiferromagneticferromagnetic transition due to substitution of $\mathrm{Co}$ - or Ni-ions for manganese ions. According to $[1,2]$ the compositions $\mathrm{La}\left(\mathrm{Mn}_{-\mathrm{x}} \mathrm{B}_{\mathrm{x}}\right)_{3}(\mathrm{~B}=\mathrm{Co}, \mathrm{Ni})$ exhibit the ferromagnetic ordering in the range $0.2<\mathrm{x}<0.5$. There is no general agreement concerning the charge distribution and exchange interactions in $\mathrm{La}\left(\mathrm{Mn}_{1-\mathrm{x}} \mathrm{B}_{\mathrm{x}}\right) \mathrm{O}_{3} \quad(\mathrm{~B}=\mathrm{Ni}, \mathrm{Co})$ perovskite. The purpose of the present study is to clarify the mechanism of exchange interactions in mixed manganites and to show how the properties change with the replacement of La by Eu, Gd, Tb, Dy or Y.

\section{EXPERIMENTAL}

Our samples $\mathrm{RE}\left(\mathrm{Mn}_{1-\mathrm{x}} \mathrm{B}_{\mathrm{x}}\right) \mathrm{O}_{3}(\mathrm{RE}=\mathrm{Eu}, \mathrm{Gd}, \mathrm{Tb}, \mathrm{Dy}, \mathrm{Y} ; \mathrm{B}=\mathrm{Ni}, \mathrm{Co})$ were synthesized by mixing in stoichiometric ratios of $\mathrm{R}_{2} \mathrm{O}_{3}, \mathrm{MnO}_{2}, \mathrm{NiO}$ or $\mathrm{Co}_{3} \mathrm{O}_{4}$ and then heating under high pressure conditions $\left(\mathrm{P}=4 \mathrm{GPa}, \mathrm{T}=1400^{\circ} \mathrm{C}\right)$. The powder $\mathrm{X}$-ray diffraction study showed the samples to be clean single phase. All the samples have the perovskite structure with orthorhombic unit cell. The unit cell volume decreases gradually with decreasing rare-earth ionic radius.

\section{RESULTS AND DISCUSSION}

The results of measurements of ac- magnetic susceptibility are displayed in Fig. 1 where the very sharp peaks are observed for $\mathrm{RE}\left(\mathrm{Mno.3} \mathrm{Co}_{0.5}\right)_{3}$. These anomalies are associated with the formation of magnetic order at temperatures below $\mathrm{T}_{\mathrm{C}}$. Results of ac-susceptibility measurements for $\mathrm{RE}\left(\mathrm{Mn}_{0.5} \mathrm{Ni}_{0.5}\right) \mathrm{O}_{3}$ differ noticeably from those obtained for Co-containing perovskites (Fig.1). Ni-containing compounds are characterized with a much higher magnetic susceptibility below their Curie temperatures than Co-containing ones.

Magnetization vs field curve for $\mathrm{Y}\left(\mathrm{Mn}_{0.5} \mathrm{Co0.5}\right) \mathrm{O}_{3}$ at $30 \mathrm{~K}$ measured after cooling in $\mathrm{H}=300$ Oe is presented in Fig.2. At high fields a large magnetic hysteresis is observed. Magnetic hysteresis decreases with decreasing field. Such a behavior could be a consequence of the first order metamagnetic transition. The $\sigma(H)$ dependences for $\mathrm{RE}_{(\mathrm{M}}\left(\mathrm{Mn}_{0.5} \mathrm{Co}_{0.5}\right) \mathrm{O}_{3}$ $(\mathrm{RE}=\mathrm{Gd}, \mathrm{Tb}, \mathrm{Dy})$ are similar to those obtained for $\mathrm{Y}(\mathrm{Mn} 0.5 \mathrm{Co} .5) \mathrm{O}_{3}$. It is interesting to note that the residual magnetization and coercive field for the heavy rare earth manganites are lower than those established for $\mathrm{Eu}\left(\mathrm{Mn}_{0.5} \mathrm{CO}_{0.5}\right)_{3} \mathrm{O}_{3}$ at $4.2 \mathrm{~K}$. It is apparently caused by the fact that magnetic structure of the heavy rare earth compounds differs from that of Eu( $\left.\mathrm{Mn}_{0.5} \mathrm{CO}_{0.5}\right) \mathrm{O}_{3}$. The field $\mathrm{H}_{\mathrm{cr}}$ at which the metamagnetic transition takes place decreases with increasing temperature. The sharp peak of $\mathrm{FC}$ (field cooled) magnetization of $\left.\mathrm{Tb}_{(\mathrm{CO}} \mathrm{CO}_{0.5} \mathrm{Mno.5}\right) \mathrm{O}_{3}$ at $\mathrm{H} \geq 400$ Oe appears near the Curie temperature. The temperature at which the FC magnetization maximum appears is 
shifted to lower temperatures with increasing field value. We have observed no peak of $F C$ magnetization near $T_{C}$ for

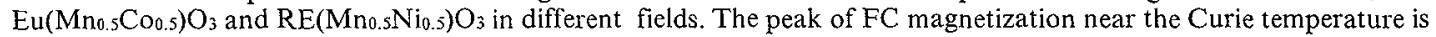
apparently due to the metamagnetic transition.

The increasing Co-content above $x=0.5$ up to $x=0.7$ does not lead to the change of Curie temperature. The decreasing Co-content leads to the supression of the long-range magnetic order. Below $64 \mathrm{~K}$ the FC magnetization of $\mathrm{Gd}\left(\mathrm{C}_{0.25} \mathrm{Mn}_{0.75}\right)_{3}$ is higher than $\mathrm{ZFC}$ (zero field cooled) one however no anomaly has been observed near $64 \mathrm{~K}$. Both ZFC and FC magnetization have maxima at 52 and $33 \mathrm{~K}$ respectively. Below $18 \mathrm{~K} \mathrm{FC}$ magnetization is directed antiparallel to the external field. The compensation temperature (when $M=0$ ) shifts towards the lower values with increasing external field. Such a behavior might arise from a system of ferrimagnetic clusters. Magnetic moments of clusters are gradually freezing below $64 \mathrm{~K}$. At low temperatures magnetic moments of Gd ions are ordered due to f-d exchange interactions. Each Gd ion in the ferrimagnetic cluster is antiferromagnetically coupled to its nearest Co and Mn neighbors, what results in a decrease of magnetization with decreasing temperature. The externai magnetic field should be higher than the internal anisotropy field necessary to reorient the magnetic moments at low temperatures. We have observed similar magnetic behavior for $\mathrm{Tb}\left(\mathrm{Mn}_{0.75} \mathrm{Co}_{0.25}\right) \mathrm{O}_{3}$. It is worth to notice that we did not detect the compensation point for $\mathrm{RE}\left(\mathrm{M}_{0.3} \mathrm{~B}_{0.5}\right) \mathrm{O}_{3}(\mathrm{RE}=\mathrm{Gd}, \mathrm{Tb}, \mathrm{Dy})$ compounds as it was earlier found for ferrites with the garnet structure. A minimum in the temperature dependence of magnetization was found for $\mathrm{Tb}\left(\mathrm{Mn}_{0.5} \mathrm{Co0.5}\right) \mathrm{O}_{3}$ at $8 \mathrm{~K}$, however the magnetization of $\mathrm{Dy}\left(\mathrm{Mno}_{5} \mathrm{Co}_{0.5}\right) \mathrm{O}_{3}$ increases strongly with decreasing temperature. It is possible that the rare earth ions sublattice is paramagnetic in the whole temperature range below the Curie temperature.

We assume that the samples of $\mathrm{RE}\left(\mathrm{Mn}_{1_{x} \mathrm{C}} \mathrm{Co}_{\mathrm{x}}\right) \mathrm{O}_{3}$ with $\mathrm{Co}$ - content below $\mathrm{x}=0.5$ contain an appreciable amount of $\mathrm{Mn}^{3+}$ and $\mathrm{Co}^{3+}$ ions. In the region $\mathrm{x} \geq 0.5$ cobalt and manganese ions are in $2+$ and $4+$ valence states, respectively. It is reasonably to assume that the $\mathrm{Co}^{2+}$ and $\mathrm{Mn}^{4+}$ ions are ordered in considerable extent making up a rocksalt type lattice of the magnetic ions. The ionic ordering leads to the well defined Curie temperature (Fig. 1). In the range $0<x<0.3$ the ferromagnetism arises due to $\mathrm{Mn}^{3+}-\mathrm{O}-\mathrm{Mn}^{3+}$ superexchange interactions in agreement with Goodenough consideration [1]. For $x \geq 0.3$ ferromagnetism results from superexchange interactions between neighboring $\mathrm{Co}^{2+}$ and $\mathrm{Mn}^{4+}$ ions as it was suggested earlier by Blasse [2]. In the compositional range $0.5<x<0.8$ the chemical phase separation into phases consisting of $\mathrm{Co}^{2+}$ and $\mathrm{Mn}^{4+}$ ionic ordered domains and $\mathrm{Co}^{3+}$ ones seems to exist. The chemical phase separation leads to the sharp transition to magnetically ordered state for Co - rich compounds. The paramagnetic state of $\mathrm{RE}$-sublattice for the ionic ordered phase can be understood if the supertransfered fields from $\mathrm{Co}^{2+}\left(\mathrm{Ni}^{2+}\right)$ and $\mathrm{Mn}^{4+}$ ions at rare earth ions have opposite signs.

The decrease of the size of rare earth ions leads to increase of crystal structure distortions and decrease of ferromagnetic $\mathrm{Co}^{2+}-\mathrm{O}^{2-} \mathrm{Mn}^{4+}$ superexchange interactions resulting in the noncollinear magnetic structure of $\mathrm{RE}\left(\mathrm{Co} .5 \mathrm{Mn}_{0.5}\right) \mathrm{O}_{3}$ $(\mathrm{RE}=\mathrm{Gd}, \mathrm{Tb}, \mathrm{Dy}, \mathrm{Y})$. The noncollinear magnetic structure transforms into collinear one in the external magnetic field.

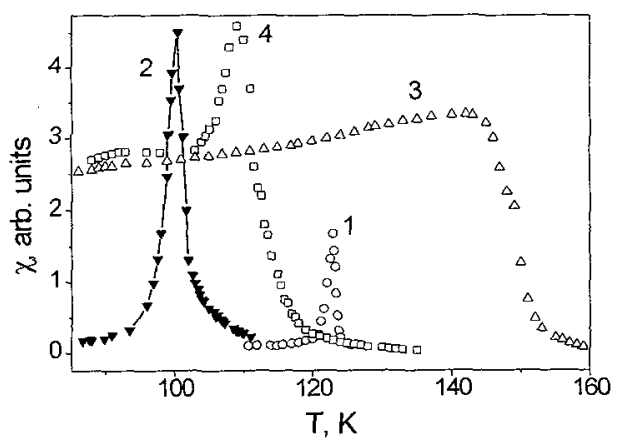

Figure 1: Ac susceptibility vs temperature for $\mathrm{RE}(\mathrm{Mn} 0.5 \mathrm{Co} .5) \mathrm{O}_{3}$ (RE=Eu - curve 1, Dy - 2) and $\mathrm{RE}(\mathrm{Mnn}, 5 \mathrm{Nin} .5) \mathrm{O}_{3}(\mathrm{RE}=\mathrm{Eu}-$ curve $3, \mathrm{~Tb}-4)$

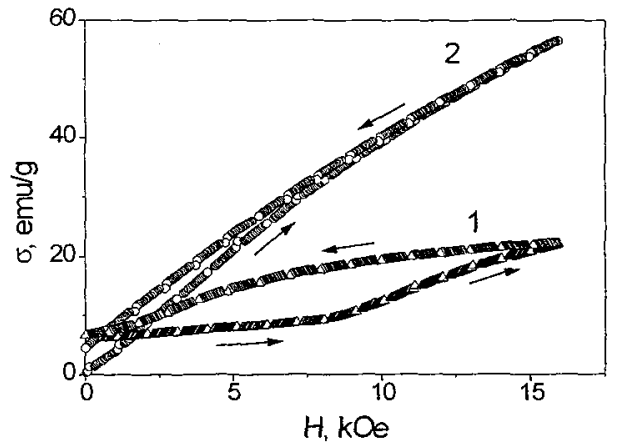

Figure 2: $\sigma(\mathrm{H})$ dependence for $\mathrm{Y}(\mathrm{Mn} 0.5 \mathrm{Co} .5) \mathrm{O}_{3}$ at 30 $\mathrm{K}(\mathrm{l})$ and $\mathrm{Tb}(\mathrm{Mn} 0.5 \mathrm{Nio.s}) \mathrm{O}_{3}$ at $4.2 \mathrm{~K}(2)$

\section{Acknowledgments}

The work was supported by Belarus Fund for Fundamental Research.

\section{References}

[1] Goodenough J.B.,Wold A., Arnott R.J, Menyuk N., Phys. Rev. 124 (1961) 373-390.

[2] Blasse G., J.Phys. Chem. Solids. 26 (1965) 1969-1972. 